\title{
Effect of Pre and Post Emergence Herbicides to Weeds Control in Corn Field
}

\author{
Mohammad Hassan Baniasadi
}

Jobholder of Agriculture, Bank Management of Fars province

\begin{abstract}
The aim of this comparative study was evaluation of pre and post emergence herbicides Effect to control weeds in corn field. Experiment was conducted as a randomized complete block design with three replications. The treatments included: no weed control, weed, complete mechanical control, Nicosulfuron herbicides (two liters per hectare) as pre-and Erradican 4 liters per hectare as post emergence. Some properties were studied such as the dry weight of weed species, plant height, seed number on the cob, seed yield, 1000seed weight, biological yield. Totally, result showed that application of herbicide led to reduction of damages caused by weeds, also, it was determined that using of Nicosulfuron+ Erradican had highest effect on weed control in compare to Nicosulfuron or Erradicanaplication. application of Nicosulfuron, Erradican, Nicosulfuron+ Erradican and complete mechanical control showed 45, 38, 58 and 84\% seed yield increasing in compare to no weed control.
\end{abstract}

Keywords-Corn, Herbicides, Weeds.

\section{INTRODUCTION}

Maize (Zea mays L.) being one of the most important cerealsof the world and has attained a commercial crop status and hasscope to increase the present maize yields. Selecting a preemergence (PRE) and postemergence (POST) herbicide program that has the greatest efficacy can be difficult for corn producers and is highly dependent on weed spectrum (Stewart et al., 2012). Management of weedsis considered to be an important factor for achieving higherproductivity. Due to increased cost and nonavailability of manuallabour in required quantity timely for hand weeding, role ofherbicide is significant preposition herbicides not only controlthe weeds timely and effectively but also offer great scope forminimizing the cost of weed control irrespective of situation.Use of pre and postemergence application of herbicides wouldmake herbicidal weed control more acceptable to farmers whichwill not change the existing agronomic practices but will allowfor complete control of weeds (Gower et al., 2002). Usage of pre-emergenceherbicides assumes greater importance in the www.ijeab.com view of theireffectiveness from initial stages. Pre-emergent application ofherbicides will control the weeds up to 25 days and after thatpost emergent application is given so that further growth ofweeds can also be controlled. Preemergence and post emergence herbicides will be an ideal means for controlling theweeds in view of economics and effectiveness in maize (Haji et al., 2012). The aim of this comparative study was evaluation of pre and post emergence herbicides Effect to control weeds in corn field.

\section{MATERIAL AND METHODS}

Experiment was conducted as a randomized complete block design with three replications. The treatments included: no weed control, weed, complete mechanical control, Nicosulfuronherbicides (two liters per hectare) as pre- and Erradican 4 liters per hectare as post emergence. 15 plots were used as experimental units with 6 cultivate lines and $5 \mathrm{~m}$ length, $75 \mathrm{~cm}$ placed between rows and between plots, Also $3 \mathrm{~m}$ was considered between blocks. S.C704 cultivar used at our study. Some properties were studied such as the dry weight of weed species, plant height, seed number on the cob, seed yield, 1000seed weight, biological yield.SAS statistical software was performed for analysisand by Duncan's multiple range test used at the level of $5 \%$ for mean comparisons.

\section{RESULT AND DISCUSSION}

Dry weight of weed species:The results showed that the treatments led to decreasing in dry weight of weed, application of Nicosulfuron,Erradican, Nicosulfuron+ Erradican and complete mechanical control showed 50, 42, 92 and $97 \%$ decreasing of weed dry weight in compare to no weed control. Also results showed that Nicosulfuron+ Erradican application led to 85 and $87 \%$ decreasing in compare to Nicosulfuron and Erradican, respectively.Singhet al., (2001) reported that while the weed management methods significantly reduced the intensity of weeds anddry matter, two manual weeding at 25 and 45 days aftersowing were found the mosteffective in reducing theintensity and dry matter accumulation of weeds

Page | 502 
over theother methods of the weed control.Fayed et al., (1983), who reported that application ofherbicide significantly decreased the fresh weight of totalwinter weeds in comparison to unweeded treatments.

Plant height:The results showed that the treatments led to an increase in plant height, application of Nicosulfuron,Erradican, Nicosulfuron+ Erradican and complete mechanical control showed 12, 9, 23 and 34\% plant height increasing in compare to no weed control. Also results showed that Nicosulfuron+ Erradican application led to 9 and $12 \%$ increasing in compare to Nicosulfuron and Erradican, respectively.It is well known that weeds interfere with crop plants causing serious impacts either in the competition for light, water, nutrients and space or in the allelopathy (Heap, 2014).

Seed number on the cob:The results showed that the treatments led to an increase in seed number, application of Nicosulfuron,Erradican, Nicosulfuron+ Erradican and complete mechanical control showed 33, 31, 36 and $41 \%$ seed number increasing in compare to no weed control. Also results showed that Nicosulfuron+ Erradican application led to 2 and $3 \%$ increasing in compare to Nicosulfuron and Erradican, respectively.Faster growth of weeds is disadvantageous for light and hence photosynthesis needed for plants (Williams et al., 2010) through this light deprivation less energy is available to crop plant formetabolic production and hence growth, yield and itsquality of crops will be reduced. In addition, weedswith branched, vigorous root systems inhibit thedevelopment of crops through severe nutrition deprivation (Isik et al., 2006).

1000seed weight:The results showed that the treatments led to an increase in 1000seed weight, application of Nicosulfuron,Erradican, Nicosulfuron+ Erradican and complete mechanical control showed 25, 20, 33 and 49\% 1000seed weight increasing in compare to no weed control. Also results showed that Nicosulfuron+ Erradican application led to 6 and $10 \%$ increasing in compare to Nicosulfuron and Erradican, respectively.Martin et al., (2001) concluded that the effect of crop competition on weed growth resulted in a conservative estimate of the critical period of weed control.

Seed yield: The results showed that the treatments led to an increase in seed yield, application of Nicosulfuron,Erradican, Nicosulfuron+ Erradican and complete mechanical control showed 45, 38, 58 and $84 \%$ seed yield increasing in compare to no weed control. Also results showed that Nicosulfuron+ Erradican application led to 9 and $14 \%$ increasing in compare to Nicosulfuron and Erradican, respectively. Whytok et a (1995) stated that the highest costof weed control in relation to the often small effects ofweed competition on yield suggest that herbicides are agood target for reducing the cost of inputs in crops, Similar observation was also reported by Tiwari andKurchania, (1993).

Biological yield:The results showed that the treatments led to an increase in biological yield, application of Nicosulfuron,Erradican, Nicosulfuron+ Erradican and complete mechanical control showed 36, 27, 50 and $62 \%$ biological yield increasing in compare to no weed control. Also results showed that Nicosulfuron+ Erradican application led to 9 and $18 \%$ increasing in compare to Nicosulfuron and Erradican, respectively.These results are in line with thoseobtained by Chauhan et al.,(2005), Saudy,(2004), Sharma andJain, (2002) and Sharma et al., (2002).

Totally, result showed that application of herbicide led to reduction of damages caused by weeds, also, it was determined that using of Nicosulfuron+ Erradican had highest effect on weed control in compare to Nicosulfuron or Erradicanaplication. application of Nicosulfuron, Erradican, Nicosulfuron+ Erradican and complete mechanical control showed 45, 38, 58 and $84 \%$ seed yield increasing in compare to no weed control.

Table.1: Means Comparison in Response to Treatments

\begin{tabular}{|c|c|c|c|c|c|c|c|c|c|c|c|}
\hline & $\begin{array}{l}\text { Dry weight of } \\
\text { weed (g/plot) }\end{array}$ & $\begin{array}{l}\text { Plant heigh } \\
\text { (m) }\end{array}$ & & $\begin{array}{l}\text { Seed numbe } \\
\text { on the cob }\end{array}$ & & $\begin{array}{l}\text { 1000seed } \\
\text { weight }(\mathrm{g})\end{array}$ & & $\begin{array}{l}\text { Seed yielc } \\
(\mathrm{kg} / \mathrm{ha})\end{array}$ & & $\begin{array}{r}\text { Biological } \\
\text { yield }(\mathrm{kg} / \mathrm{h}\end{array}$ & \\
\hline No weed control & 180 & 1.80 & d & 600 & d & 124 & $\mathrm{e}$ & 7440 & $\mathrm{e}$ & 17325 & $\mathrm{e}$ \\
\hline Nicosulfuron & 90 & 1.90 & $\mathrm{c}$ & 700 & $\mathrm{c}$ & 140 & $\mathrm{c}$ & 9800 & $\mathrm{c}$ & 22034 & $\mathrm{c}$ \\
\hline Erradican & 105 & 1.85 & $\mathrm{~cd}$ & 690 & $\mathrm{c}$ & 135 & $d$ & 9315 & d & 20354 & d \\
\hline Nicosulfuron+ Erradican & 15 & 2.10 & $\mathrm{~b}$ & 721 & $\mathrm{~b}$ & 150 & $\mathrm{~b}$ & 10815 & $\mathrm{~b}$ & 24348 & $\mathrm{~b}$ \\
\hline $\begin{array}{l}\text { Complete mechanical } \\
\text { control }\end{array}$ & 5 & 2.30 & $\mathrm{a}$ & 750.4 & $\mathrm{a}$ & 170 & $\mathrm{a}$ & 12756 & $\mathrm{a}$ & 26400 & $\mathrm{a}$ \\
\hline
\end{tabular}




\section{REFERENCES}

[1] Chauhan, Y.S., M.K. Bhargava and V.K. Jain, 2005. Weed management in Indian mustard(Brassica juncea). Indian J. Agron., 50(2): 149-151.

[2] Fayed, M.T., M.T. Mostafa and E.E. Hassanein, 1983.Increasing the efficiency of herbicides in controllingcotton weeds by one light hoeing. Proc. 1st Conf.Agron., Egypt, Soc., of Crop Sci., 2: 679-688.

[3] Gower, S.A., Loux, M.M., Cardina, J. and Harrison, S.K., 2002. Effect of Planting Date, Residual Herbicide, and Postemergence Application Timing on Weed Control and Grain Yield in Glyphosate-Tolerant Corn (Zea mays) 1. Weed Technology, 16(3), pp.488494.

[4] Haji, I.D., Hunshal, C., Malligwad, L., Basavaraj, B. and Chimmad, V., 2012. Effect of pre and post emergence herbicides on weed control in maize (Zea mays. L.). Karnataka Journal of Agricultural Sciences, 25(3).

[5] Heap, I., 2014. Herbicide resistant weeds. In Integrated Pest Management (pp. 281-301). Springer Netherlands.

[6] Isik, D., Mennan, H., Bukun, B., Oz, A. and Ngouajio, M., 2006. The Critical Period for Weed Control in Corn in Turkey 1. Weed technology, 20(4), pp.867872.

[7] Martin, S.G., L.F. Friesen and R.C. Van Acker, 2001.Critical period of weed control in spring canola.Weed Sci., 49: 326-333.

[8] Saudy, H.S.S., 2004. Effect of weed management andnitrogen fertilization on canola crop and associatedweeds. Ph.D. Sci., Thesis Faculty of Agric., AinShams Univ., Egypt.

[9] Sharma, O.L. and N.K. Jain, 2002. Effect of herbicideson weed dynamics and seed yield of Indian mustard. Indian J. Agric., Sci., 72:322-324.

[10] Sharma, R.P., P. Singh and P.L. Maliwal, 2002. Effect of weed management and phosphorus applied to Indian mustard. Indian J. Agric.,Sci., 72(8): 461-463.

[11] Singh, H., B.P. Singh and H. Prasad, 2001. Weedmanagement in Brassica species. Indian $\mathrm{J}$. Agron,.46(3): 533-537.

[12] Stewart, C.L., Soltani, N., Nurse, R.E., Hamill, A.S. and Sikkema, P.H., 2012. Precipitation influences preand post-emergence herbicide efficacy in corn. American Journal of Plant Sciences, 3(09), p.1193.

[13] Tiwari, J.P. and S.P. Kurchania, 1993. Chemicalcontrol of weeds in Indian mustard (Brassicajuncea). Indian J. Agric. Sci., 63(5): 272-275. www.ijeab.com
[14] Whytok, G.P., I.J. Bingham and R.E.L. Naylor, 1995. Developing cost-effective strategies for weed control in winter oilseed rape. Proc. Brighton Crop Prot. Conf. Weeds, 3: 883-888.

[15] Williams, M.M., Boerboom, C.M. and Rabaey, T.L., 2010. Significance of atrazine in sweet corn weed management systems. Weed Technology, 24(2), pp.139-142. 